\title{
CARD11 Gene
}

National Cancer Institute

\section{Source}

National Cancer Institute. CARD11 Gene. NCI Thesaurus. Code C60668.

This gene plays a role in apoptotic regulation. 